\title{
Morphology of late Quaternary submarine landslides along the U.S. Atlantic continental margin
}

\author{
David C. Twichell ${ }^{\mathrm{a}, *}$, Jason D. Chaytor ${ }^{\mathrm{b}}$, Uri S. ten Brink ${ }^{\mathrm{a}}$, Brian Buczkowski ${ }^{\mathrm{a}}$ \\ a U.S. Geological Survey, Woods Hole, MA, USA \\ ${ }^{\mathrm{b}}$ Woods Hole Oceanographic Institution, Woods Hole, MA, USA
}

\section{A R T I C L E I N F O}

\section{Article history:}

Received 29 January 2008

Received in revised form 26 January 2009

Accepted 30 January 2009

\section{Keywords:}

landslides

continental margin

Atlantic Ocean

sediments

slope processes

\begin{abstract}
A B S T R A C T
The nearly complete coverage of the U.S. Atlantic continental slope and rise by multibeam bathymetry and backscatter imagery provides an opportunity to reevaluate the distribution of submarine landslides along the margin and reassess the controls on their formation. Landslides can be divided into two categories based on their source areas: those sourced in submarine canyons and those sourced on the open continental slope and rise. Landslide distribution is in part controlled by the Quaternary history of the margin. They cover $33 \%$ of the continental slope and rise of the glacially influenced New England margin, 16\% of the sea floor offshore of the fluvially dominated Middle Atlantic margin, and 13\% of the sea floor south of Cape Hatteras. The headwall scarps of open-slope sourced landslides occur mostly on the lower slope and upper rise while they occur mostly on the upper slope in the canyon-sourced ones. The deposits from both landslide categories are generally thin (mostly 20-40 m thick) and comprised primarily of Quaternary material, but the volumes of the open-slope sourced landslide deposits can be larger $\left(1-392 \mathrm{~km}^{3}\right)$ than the canyonsourced ones (1-10 $\left.\mathrm{km}^{3}\right)$. The largest failures are located seaward of shelf-edge deltas along the southern New England margin and near salt domes that breach the sea floor south of Cape Hatteras. The spatial distribution of landslides indicates that earthquakes associated with rebound of the glaciated part of the margin or earthquakes associated with salt domes were probably the primary triggering mechanism although other processes may have pre-conditioned sediments for failure. The largest failures and those that have the potential to generate the largest tsunamis are the open-slope sourced landslides.
\end{abstract}

Published by Elsevier B.V.

\section{Introduction}

The 2004 Sumatra tsunami drew attention to the devastation that tsunamis can cause in tectonically active settings, yet modeling studies of tsunamis generated by large landslides (Mader, 2001; Bondevik et al., 2005; and Gisler et al., 2006) indicate that even passive margins are not spared from this type of hazard. In fact one of the early observed examples of submarine slope failures was the landslides and related turbidity currents generated by the 1929 earthquake near the Grand Banks offshore of Nova Scotia, Canada (Heezen and Ewing, 1952). These landslides generated a 3-8-m wave amplitude along parts of the Newfoundland coast with a maximum runup of $13 \mathrm{~m}$ (Fine et al., 2005).

Several summaries describe the distribution and extent of submarine landslides on the passive margins around the North Atlantic Ocean (i.e. Weaver et al., 2000; Piper and McCall, 2003; Huhnerbach et al., 2004; and Masson et al., 2006), and studies specific

\footnotetext{
* Corresponding author. U.S. Geological Survey, 384 Woods Hole Road, Woods Hole, MA 02543, USA. Tel.: +1 508457 2266; fax: +1 5084572310.

E-mail address: dtwichell@usgs.gov (D.C. Twichell).
}

to the U.S. Atlantic margin have been summarized by Embley and Jacobi (1986), Booth et al. (1993), and Chaytor et al. (2007). Prior to the widespread introduction of acoustic mapping methods, techniques for identifying and mapping landslides were based on widely spaced seismic profiles and piston cores (Embley and Jacobi, 1986; and Pratson and Laine, 1989 and references in these reviews). GLORIA sidescan sonar imagery provided the first continuous coverage image of this margin, and allowed a more detailed mapping of their spatial extent (EEZ-SCAN 87, 1991; Booth and O'Leary, 1991; Schlee and Robb, 1991; Popenoe and Dillon, 1996). The availability of high-quality multibeam bathymetric data allows detailed mapping of several geomorphic traits of the landslides that were not possible in previous data sets (McAdoo et al., 2000; Chaytor et al., 2007). For example, the location and relief of headwall scarps, the slope of landslide source areas, their height and length measures, and whether they are multistaged or single events are readily identified in these new data. While McAdoo et al. (2000) tabulated many of these traits in localized areas; the recent acquisition of multibeam bathymetry along much of the U.S. Atlantic margin (Gardner et al., 2006) allows analysis of the entire margin. Chaytor et al. (2007) used these data to map the distribution of landslides along this margin. Here we further characterize the geomorphic traits of the landslides that occurred 
during the late Quaternary and are still expressed on the sea floor. The landslides were separated into two types on the basis of their source areas, and landslide morphology and geologic setting were used to evaluate differences in the conditions that may have contributed to landslides from the two source areas.

\section{Geologic setting}

The geologic evolution of the U.S. Atlantic continental margin has been extensively documented in the literature (i.e. Poag, 1985; Vogt and Tucholke, 1986). We summarize here aspects of the evolution of this margin that are salient to landslide activity during the late Quaternary. During the initial rifting of the North Atlantic, salt deposition was probably extensive, but salt domes that disrupt the modern sea floor are present only offshore of North and South Carolina (Dillon et al., 1982). A nearly continuous carbonate platform formed along this entire margin during the Middle Jurassic to Middle Cretaceous (Poag, 1991) but presently it is only exposed along the Blake Escarpment and Blake Spur south of the study area and locally in some of the canyons off Georges Bank (Ryan et al., 1978). Cenozoic deposits are primarily siliciclastic (Tucholke and Mountain, 1986; Poag and Sevon, 1989) with Eocene chalk exposed along parts of the lower slope off southern New England and the Middle Atlantic; the region between Hudson Canyon and Cape Hatteras (Weed et al., 1974; Ryan et al., 1978; Robb et al., 1981; Tucholke and Mountain, 1986). Reworking of continental rise sediments by bottom currents was initiated during the Miocene, and constructed the Chesapeake Drift, Hatteras Drift, and Blake Outer Ridge (Mountain and Tucholke, 1985); features that are still expressed on the sea floor (Fig. 1).

Large volumes of sediment, eroded from the North American continent during the Quaternary glaciations, were deposited unevenly along this margin (Poag and Sevon, 1989). At their maximum extent, continental glaciers reached the shelf edge off Nova Scotia and supplied sediment directly to the outer shelf and upper slope (Jenner et al., 2007). Off New England the glaciers did not reach the shelf edge (Fig. 1), and large rivers transported these glacial sediments to shelf-edge deltas along much of this margin (McMaster and Ashraf, 1973; Austin et al., 1980; Schlee and Fritsch, 1983, Poag and Sevon, 1989). Quaternary deposits consist of interbedded silts and sandy silts that reach thicknesses of 400-800 m under the outer shelf and upper slope and are thin or absent on the lower slope (Poag and Sevon, 1989; Poag, 1992). South of the glacially influenced region, off the Middle Atlantic, some rivers built localized shelf-edge deltas (Fig. 1), and others supplied sediment to deep-sea fans on the upper rise (Poag, 1992). South of Cape Hatteras the Quaternary sediment is extremely thin or absent on the continental slope due to the Blake Plateau which

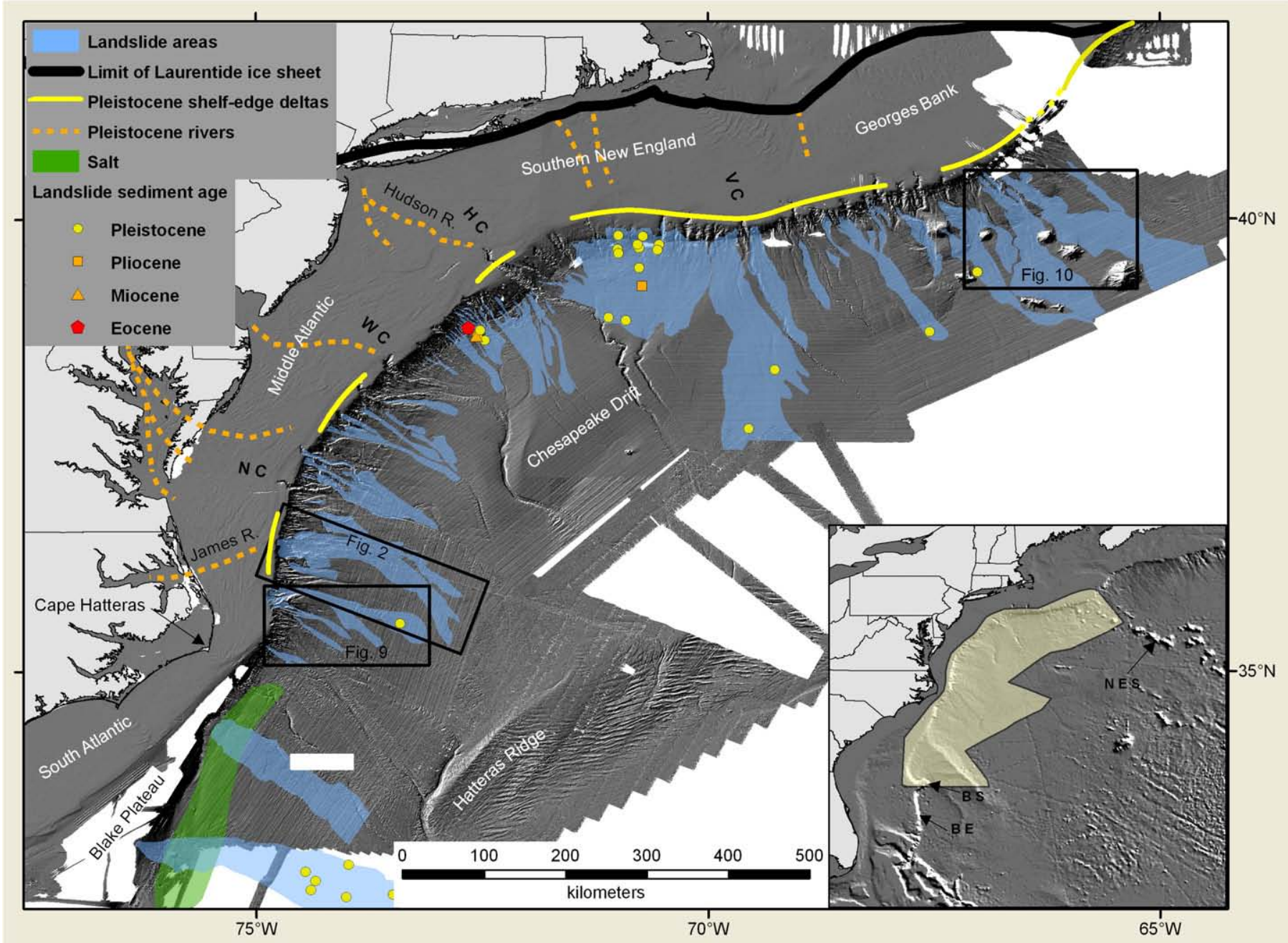

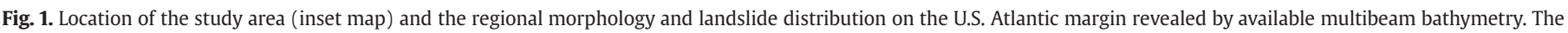

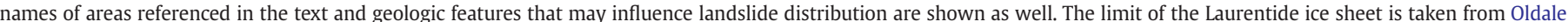

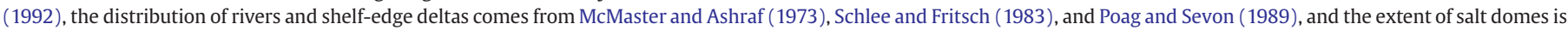

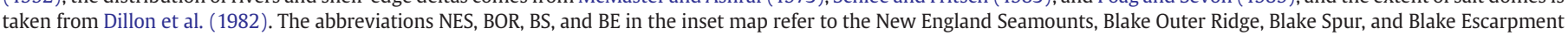

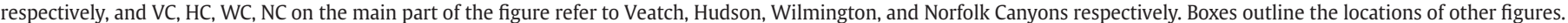


separates the continental shelf and uppermost slope from the remainder of the continental slope and rise (Poag, 1978). Sediment accumulation rates on this margin were higher during the Quaternary than during any other time since the opening of the Atlantic Ocean (Poag and Sevon, 1989).

\section{Methods}

Available bathymetry, sidescan sonar imagery, subbottom seismic profiles, and core data were incorporated into a GIS and the integration of these data provides the basis for this interpretation of landslides.

\subsection{Data}

The bathymetry used in this analysis is a compilation of multibeam swath bathymetry and soundings. Multibeam data were acquired from several sources and vary in age, sounding density, and positional accuracy. The primary data set, which made the re-evaluation of landslides possible, was acquired during 2004 and 2005 by the University of New Hampshire (UNH) in support of potential U.S. claims under the United Nations Convention on the Law of the Sea (Gardner et al., 2006). This data set provides near-continuous multibeam coverage from near the base of the continental slope (ca. $1500 \mathrm{~m}$ ) to abyssal plain depths (ca. $5000 \mathrm{~m}$ ) between the eastern end
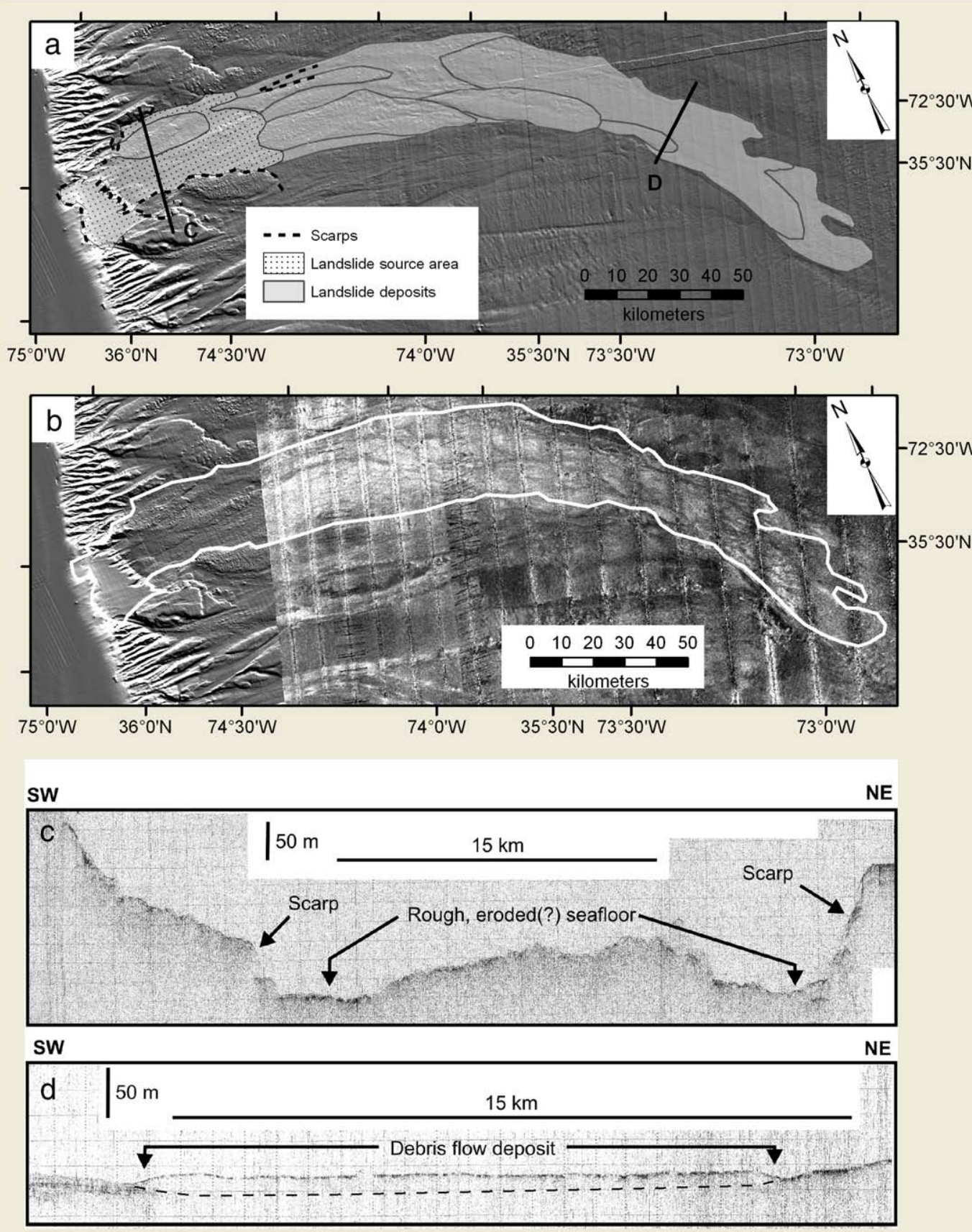

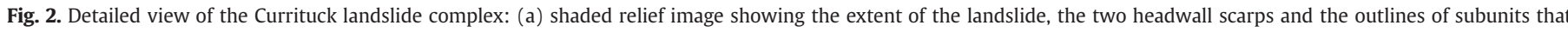

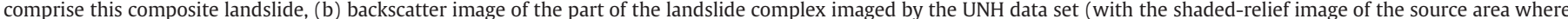

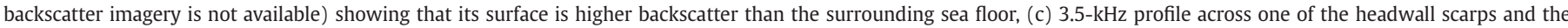

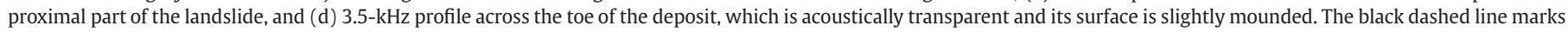
the base of the deposit. The locations of the two profiles are shown in A, and the location of A is shown in Fig. 1. 
Table 1

Characteristics of landslides on the Atlantic margin.

\begin{tabular}{llcccr}
\hline Parameter & Source & Mean & Median & Minimum & Maximum \\
\hline Length $(\mathrm{km})$ & Canyon & 71 & 60 & 9 & 159 \\
& Slope & 107 & 92 & 13 & $>291$ \\
Maximum width $(\mathrm{km})$ & Canyon & 15 & 18 & 2 & 42 \\
& Slope & 30 & 12 & 3 & 151 \\
Area $\left(\mathrm{km}^{2}\right)$ & Canyon & 760 & 384 & 12 & 3131 \\
& Slope & 3384 & 425 & 21 & 15,241 \\
Average thickness $(\mathrm{m})$ & Canyon & 11 & 10 & 5 & 20 \\
& Slope & 32 & 15 & 5 & 70 \\
Origin depth $(\mathrm{m})$ & Canyon & 764 & 665 & 92 & 2125 \\
& Slope & 1841 & 2052 & 121 & 3263 \\
Termination depth $(\mathrm{m})$ & Canyon & 2985 & 2972 & 1278 & 4240 \\
& Slope & 3110 & 3054 & 1440 & $>4735$ \\
Slope angle at origin $\left(^{\circ}\right)$ & Canyon & 6.8 & 6.8 & 1.2 & 11 \\
& Slope & 3.2 & 2.6 & 0.5 & 9 \\
Scarp height $(\mathrm{m})$ & Canyon & 647 & 225 & 63 & 1581 \\
& Slope & 118 & 64 & 3 & 1102 \\
\hline
\end{tabular}

of Georges Bank and offshore South Carolina (approximately latitude $33^{\circ} \mathrm{N}$; Fig. 1). Additional data were extracted from research institution and NOAA databases including data collected by Woods Hole Oceanographic Institution ships $R / V$ Knorr and $R / V$ Atlantis II, Lamont-Doherty Earth Observatory ships $R / V$ Ewing and $R / V$ Robert Conrad, and NOAA ships. These data provide additional coverage of portions of the continental slope not covered by the UNH data set. At this time multibeam data are not available from a large section of the slope and rise offshore Georgia and portions of the continental slope off southern New England, Georges Bank and mid-Atlantic areas (Fig. 1). Where multibeam data were not available, from the slope and rise as well as the continental shelf, sounding data from the National Ocean Service hydrographic database were employed to provide bathymetric coverage. The final map covers the ocean floor from the shoreline to depths greater than $5000 \mathrm{~m}$ and was gridded at a horizontal pixel resolution of $100 \mathrm{~m}$.

Analog $3.5-\mathrm{kHz}$ profiles, co-acquired with the GLORIA sidescan imagery (EEZ-SCAN 87, 1991) were used to map the shallow stratigraphy of the late Quaternary landslides along lines spaced 10-35 km apart. These profiles provided thicknesses of some of the deposits but had insufficient penetration into others. Airgun profiles collected during the same survey were analyzed to try to resolve the thicker deposits, but these data were too low resolution to be helpful. Consequently the thicknesses and volumes were measured on only selected landslide deposits. A sound velocity of $1500 \mathrm{~m} / \mathrm{s}$ was used to convert the measurements on the profiles to thicknesses. Although numerous seismic-reflection records have been collected across the US Atlantic continental margin many were too low resolution to resolve the shallow stratigraphy and in other cases the navigation was of insufficient quality to accurately place them on the highquality bathymetry. Of the data sets available to us, the profiles collected during the EEZ-SCAN 87 survey provided regional coverage and sufficient data density to characterize regional differenced in the landslides.

While 1400 cores have been collected within the study area over the last 60 years only 30 of these cores were recovered from the mapped landslide areas. Brief descriptions of the overall lithology and sedimentary structures for many of the cores in the study area were extracted from the National Geophysical Data Center core repository (http://www.ngdc.noaa.gov/mgg/curator/curator.html). Detailed descriptions of some cores were obtained from studies by Embley (1980), Prior et al. (1984), and Prior et al. (1986).

\subsection{Analysis}

The extent of landslides was mapped using multibeam backscatter imagery and GLORIA imagery (EEZ-SCAN 87, 1991) where other back- scatter imagery was not available, the bathymetry itself, and the $3.5-\mathrm{kHz}$ seismic profiles (Fig. 2). The surface of most landslides have a highbackscatter signature, and on the $3.5-\mathrm{kHz}$ profiles the sea floor commonly reveals a rough surface in areas of landslide excavation and an acoustically transparent horizon in the areas of landslide deposition (Fig. 2c, d). Once outlined, the dimensions of the landslide areas were tabulated along with additional measurements including the source area depth (taken as the top of the shallowest headwall scarp), termination depth, slope of the area surrounding the source area, and headwall scarp height (Table 1). Estimates of the volume of 28 landslide deposits are shown in Fig. 3. The volumes of approximately half the landslide deposits could not be estimated because their thickness was not imaged by the seismic profiles. The cores provided information on the age and internal structure of the landslide deposits.

\section{Results}

\subsection{Margin morphology}

The morphology of most of the U.S. Atlantic margin offshore of Georges Bank to Georgia is shown in the shaded-relief rendition of the bathymetry (Fig. 1), and is described here in terms of classic passive margin morphology summarized by Heezen et al. (1959). The continental slope has the steepest gradients of the margin and is mostly in the depth range of 200-2000 m, while the continental rise has significantly gentler gradients and is in greater depths.

The continental slope is heavily, but unequally, dissected by submarine canyons. Canyons are absent south of Cape Hatteras where the lower slope is separated from the upper slope by the Blake Plateau (Fig. 1). Canyons are more widely spaced off the Quaternary shelf-edge deltas south of New England and off deltas built by the paleo Hudson and James Rivers, and are more closely spaced along the remainder of the slope.

The gradient of the continental slope is variable (Fig. 4). South of Cape Hatteras the lower slope reaches gradients of $12^{\circ}$, and the upper slope rarely exceeds $6^{\circ}$. Off the James, Hudson, and southern New England Quaternary shelf-edge deltas the gradients are steepest on the lower slope reaching as high as $8-12^{\circ}$. In these areas the upper slope rarely exceeds $4^{\circ}$. The remainder of the continental slope between Cape Hatteras and Hudson Canyon and south of Georges Bank can reach gradients of $8-12^{\circ}$ but is mostly $4-8^{\circ}$ and has a fairly constant gradient across the entire slope. Locally submarine canyon walls can exceed $20^{\circ}$.

The morphology of the continental rise varies along this margin as well. South of Norfolk Canyon the upper rise is steeper $\left(1-3^{\circ}\right)$ than the lower rise $\left(0.5-2^{\circ}\right)$ shoreward of the Hatteras Outer Ridge (Fig. 4a). Between Norfolk and Veatch Canyons, the upper rise is characterized by a broad gentle terrace formed behind the pre-Quaternary Chesapeake Drift (Mountain and Tucholke, 1985) with slopes mostly less than $0.5^{\circ}$. The slope of the seaward edge of the Chesapeake Drift

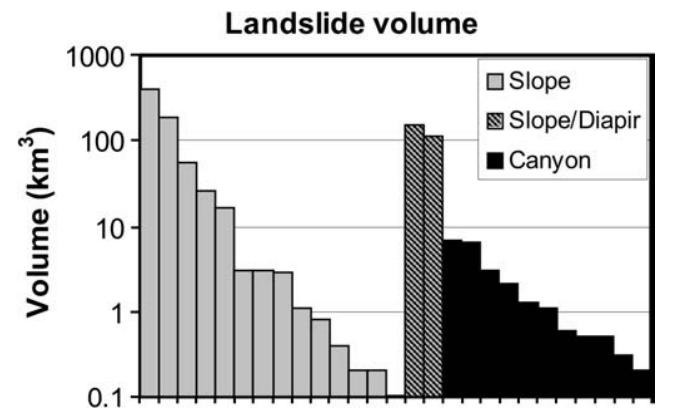

Fig. 3. Graph showing the volumes of 28 of the landslide areas of deposition that were mapped. Note that the scale is logarithmic. Of the landslides sourced on the open slope and near diapirs (also in open slope settings), nearly half ( 7 of 16) have volumes exceeding $10 \mathrm{~km}^{3}$ while none of the canyon-sourced landslide deposits exceed $7 \mathrm{~km}^{3}$. 


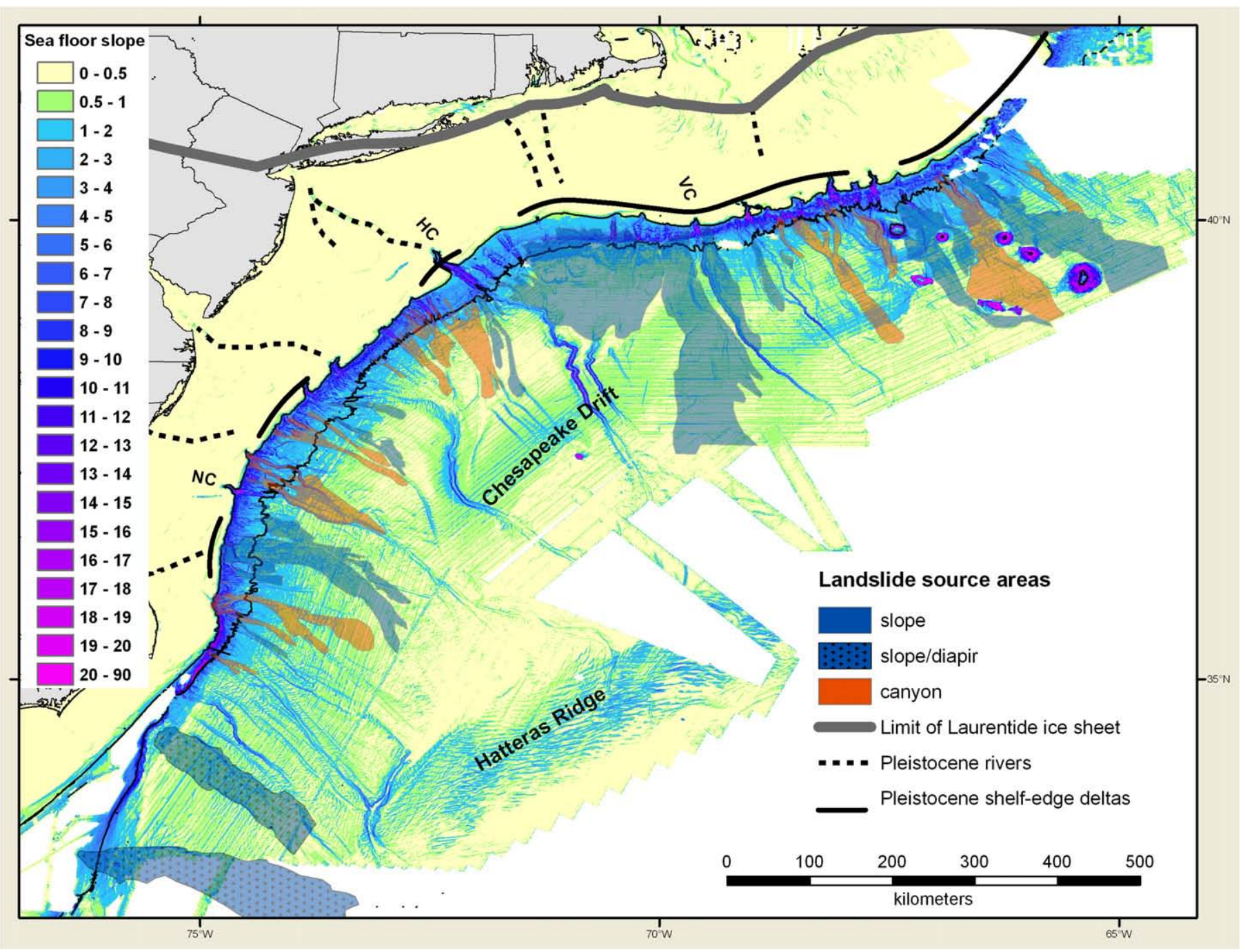

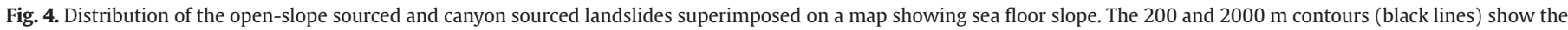
approximate shelf edge and base of slope.

increases to $0.5-2^{\circ}$. East of Veatch Canyon, off Georges Bank, the upper rise is steeper than the lower rise except where it is interrupted by the New England Seamounts. Gradients are similar to the rise south of Norfolk Canyon.

\subsection{Distribution of landslides}

A total of 48 distinct landslide complexes were mapped between the eastern end of Georges Bank and 32.5 $\mathrm{N}$ off Georgia (Figs. 1, 4). This number is considerably less than the 179 tabulated by Booth et al. (1988, 1993) and Booth and O'Leary (1991). The reasons for the difference are twofold. First, many of the landslides they tabulated were identified on widely spaced seismic profiles, and each observation was reported as a separate failure, but superimposing their locations on the multibeam data reveals that many of their identified failures can be grouped together because they fall within the boundaries of landslide complexes that were mapped using the integrated data sets. Second, several of the landslides we mapped consist of multiple overlapping failures which could not be consistently broken into individual landslides, and were therefore left grouped as composite features. The number also differs from the 55 landslides mapped by Chaytor et al. (2007) because in some cases they identified individual landslides within the larger composite features while this study is limited to just the composite landslides. Chaytor et al. (2009- this issue) tabulated 106 landslide source areas which further supports the composite nature of many of these features.

The distribution of landslide areas is not uniform along this margin. We split the margin into three regions based on the processes of sediment supply during the Quaternary: the glacially influenced margin off Georges Bank and Southern New England, the fluvially influenced region between Hudson Canyon and Cape Hatteras, and the region south of Cape Hatteras. Fifteen landslide areas were mapped off Georges Bank and southern New England, which cover 33\% of this part of the margin. Between Hudson Canyon and Cape Hatteras 31 landslide areas were mapped, which cover $16 \%$ of this part of the study area. South of Cape Hatteras, only 2 landslide areas are present that cover $13 \%$ of this part of the study area (Fig. 1).

\subsection{Landslide characteristics}

Landslides on the U.S. Atlantic margin can be grouped into two categories based on their source areas: those that originate in submarine canyons and those that originate between canyons on the open slope (Fig. 4). Booth et al. (1988) originally made this distinction, but could not differentiate the source area type in many cases in their data base. Table 1 lists several of the same characteristics tabulated by Booth et al. (1988) and allows comparison of these two landslide groups. 


\section{a Canyon Sourced Landslides}

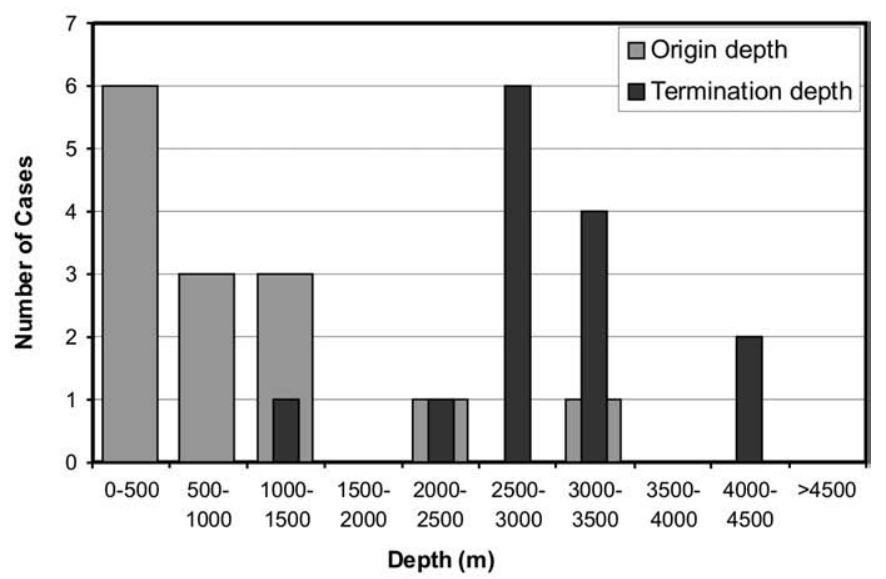

b Open-Slope Sourced Landslides

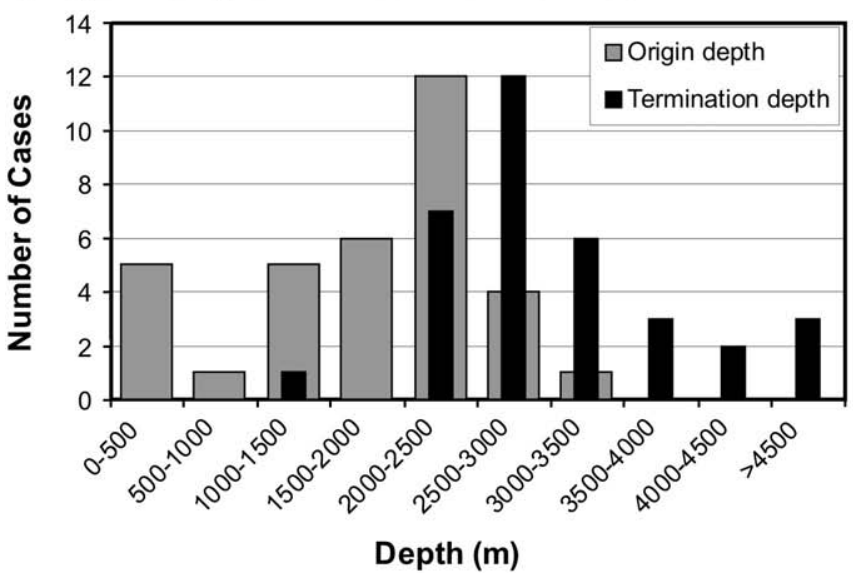

Fig. 5. Graphs showing the depths binned at 500-m increments at which canyon sourced landslides (a) and slope-sourced landslides (b) originate and terminate.

\subsubsection{Canyon sourced}

Canyon sourced landslides originate mostly on the middle and upper slope in water depths less than $1000 \mathrm{~m}$ (Fig. 5a), have areas (source area and deposit) less than $3131 \mathrm{~km}^{2}$, lengths less than $160 \mathrm{~km}$ (Table 1), they are about four times as long as they are wide (Fig. 6), and account for 14 of the landslide areas. The slope of the source area, the regional gradient of the continental slope around canyon sourced landslides, mostly exceeds $4^{\circ}$ (Fig. 7). While the area surrounding the heads of submarine canyons are mostly $4-8^{\circ}$, the canyon walls can

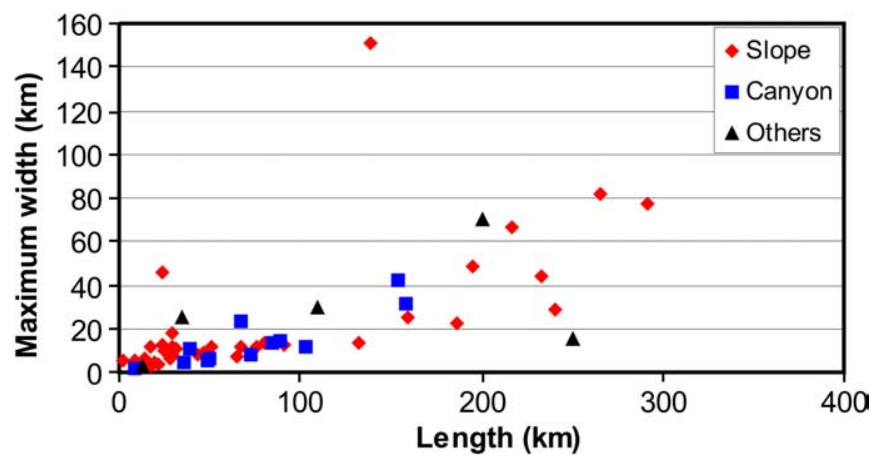

Fig. 6. Graph comparing the maximum width to the length of the two landslide types. Black triangles are from landslides in the eastern North Atlantic and Mediterranean and show the mean width vs. length (Canals et al., 2004). The two largest landslides tabulated by Canals et al. (2004), the Canary (600 km long and $90 \mathrm{~km}$ wide) and Storegga (770 km long and $115 \mathrm{~km}$ wide), are not shown because they exceed the scale of the graph.

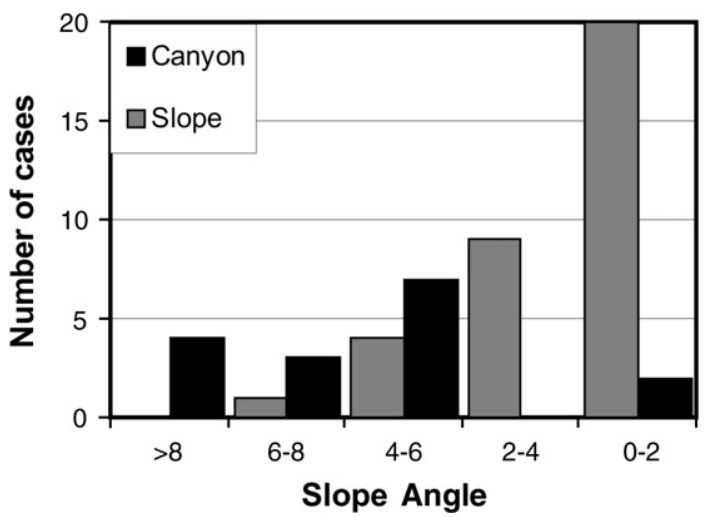

Fig. 7. Regional slope of the sea floor surrounding the source area for the canyon sourced and open-slope sourced landslides.

exceed $20^{\circ}$ (Fig. 4). The presence of numerous gullies and short scarps along canyon walls suggest that multiple failures have contributed to the deposits that cover the canyon floors and extend offshore onto the rise (Fig. 8). The surfaces of the deposits have a higher backscatter signature than the surrounding sea floor. The backscatter imagery commonly shows several elongate high-backscatter fingers on the surface of the deposit further supporting the supposition that multiple failures contributed to forming the deposit. Seismic profiles show the deposits to be 5-20 m thick (Table 1), and the measured volumes are all less than $10 \mathrm{~km}^{3}$ (Fig. 3).

\subsubsection{Open-slope sourced}

Open-slope sourced landslides originate mostly on the upper rise and lower slope in water depths of 1500-2500 m (Fig. 5b), have areas (source area and deposit) reaching $15,241 \mathrm{~km}^{2}$, lengths (other than the longest three) that are similar to the slope-sourced landslides, they also are about 4 times longer than they are wide (Fig. 6), and account for 34 of the landslide areas. The slope of the sea floor around the source areas is commonly less than $2^{\circ}$ (Fig. 7). The headwall scarps are longer and more continuous than those associated with canyonsourced landslides (Fig. 9). The distribution of scarps suggests that most of the open-slope landslides are also made up of several failures. Based on the cross-cutting relationships of the scarps, many of these open-slope landslides were initiated on the upper rise or lower slope, and retrogressive or subsequent failures shifted the source areas to shallower water depths (Fig. 9). The material from the younger and shallower failures smoothes or buries the older scarps as it travels downslope over them. The height of scarps associated with these open-slope failures are mostly less than $65 \mathrm{~m}$ (Table 1). The thickness of deposits from these failures can exceed $70 \mathrm{~m}$, and the volumes of the deposits for those from which accurate measurements could be made show that the open-slope sourced landslides can be much larger than the canyon sourced ones (Fig. 3).

\subsection{Morphology/landslide type}

The types of landslides (e.g., rotational, translational, etc.; see Locat and Lee, 2002) could not be determined from their morphologies alone. The $3.5-\mathrm{kHz}$ profiles consistently show no internal structure within the landslide deposits which suggests disintegration of the failed material and homogenization during transport (Fig. 2d). Some of the cores recovered debris flow deposits (Embley, 1980), but the limited number of cores recovered from landslide deposits ( 30 cores from 7 of the 48 landslide areas) makes generalizations as to the failure mechanism questionable; particularly in light of analysis of cores and seismic profiles by Tripsanas et al. (2008) who demonstrated that cores showing deposits from a variety of failure types were recovered from areas with acoustically transparent signatures on seismic profiles. 


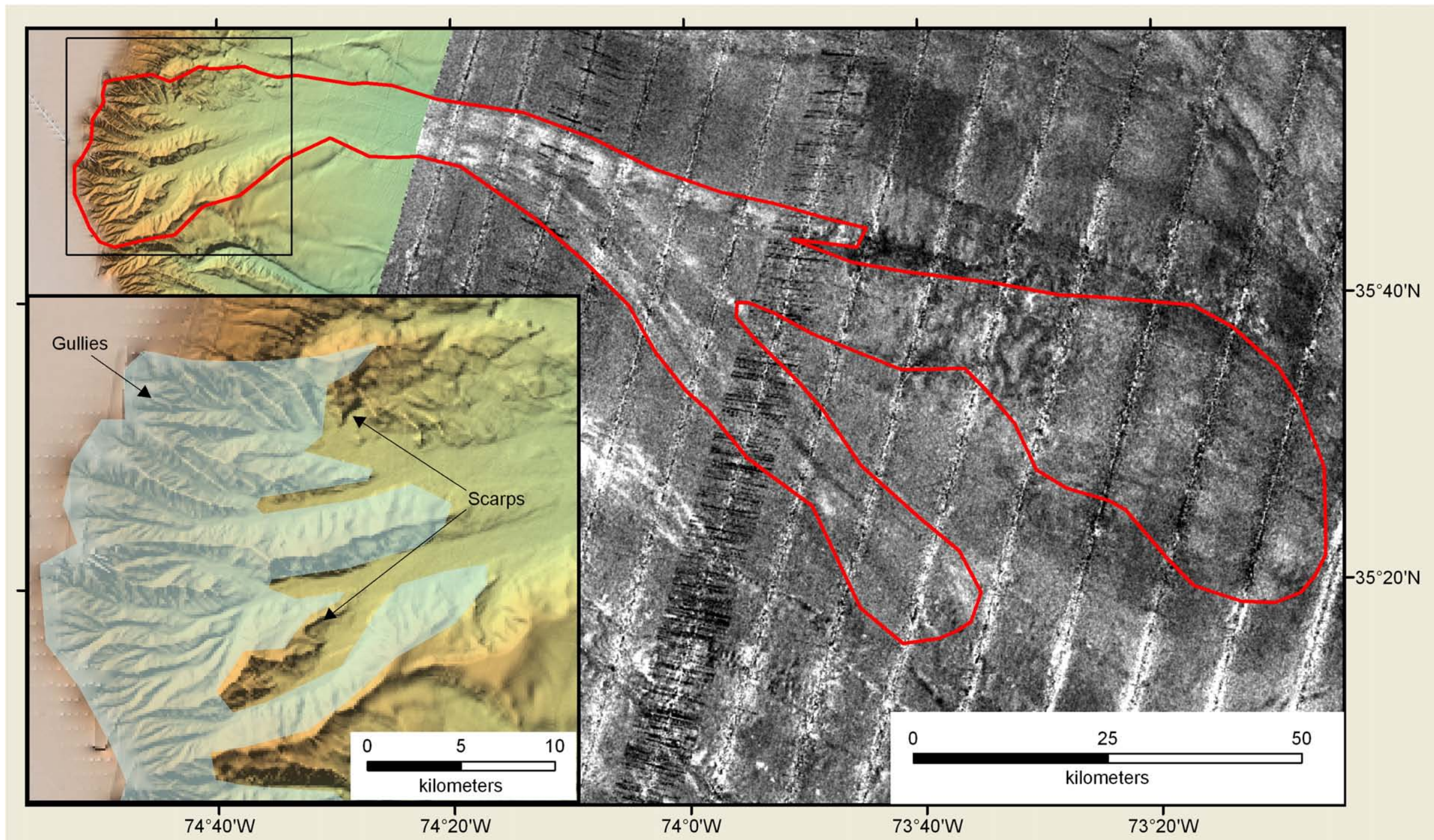

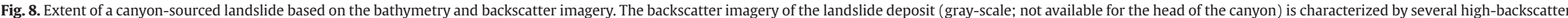
fingers suggesting the deposit consists of several smaller ones. The source area (inset) is extensively gullied (pale blue area), and headwall scarps are short suggesting small failures. 


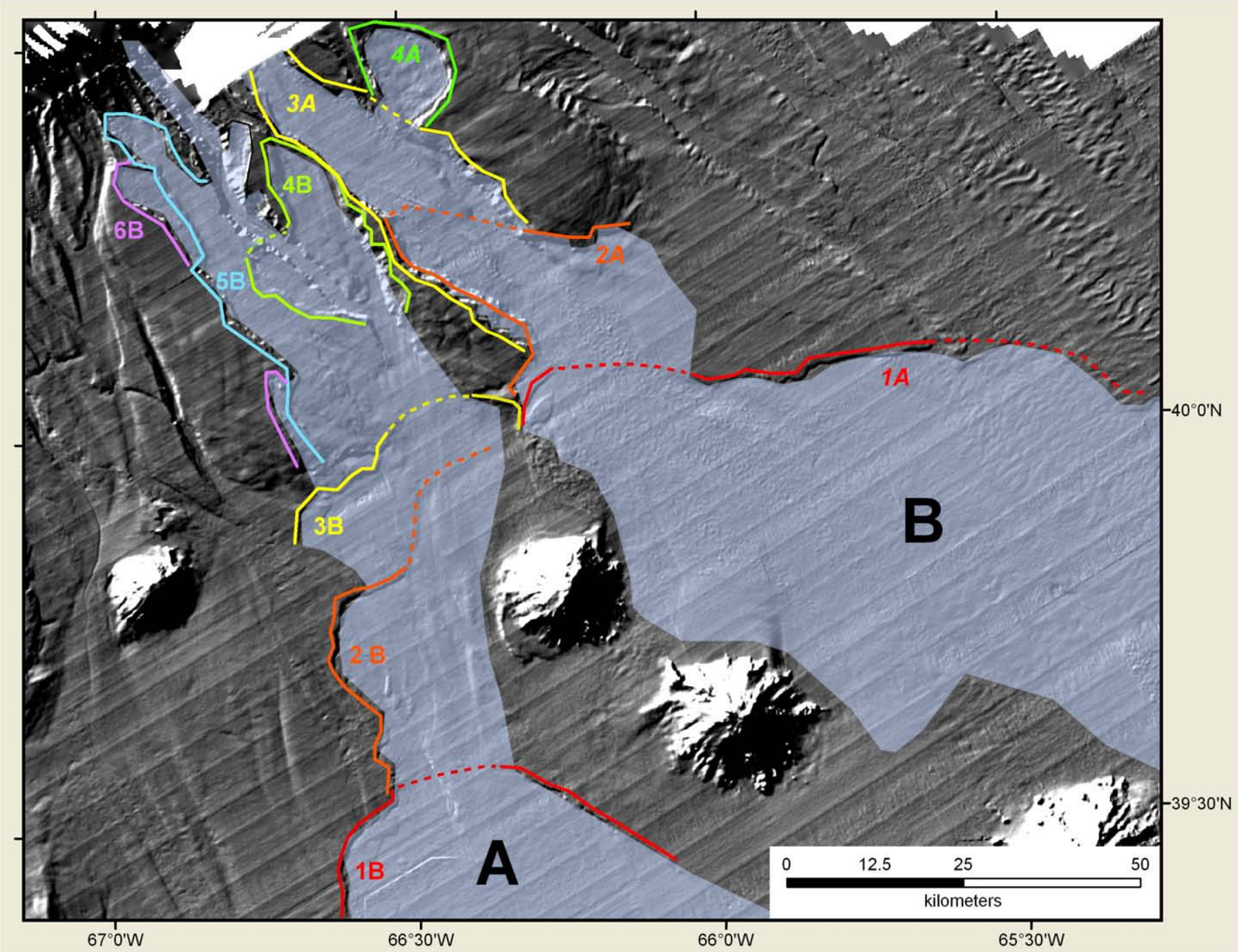

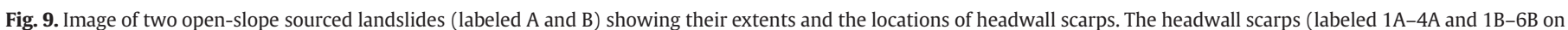

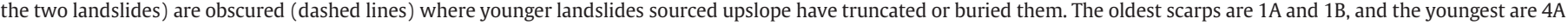
and $6 \mathrm{~B}$ showing that they were initiated on the upper rise and subsequent failures were progressively farther upslope. Location of this figure is shown in Fig. 1.

\subsection{Landslide ages}

The ages of the landslides on the U.S. Atlantic margin are discussed by Lee (2009-this issue) who found that most of them are early Holocene in age or older. The material that comprised the landslide deposits, as defined by the 30 cores mentioned above is Pleistocene in all but three cases (Fig. 1). The age of the sediment in the deposits indicates that most failures removed only a surficial skin of Quaternary sediment from the source area, and did not cut deep enough to excavate the underlying older strata. Only in landslide deposits off southern New England and south of Hudson Canyon where older strata are exposed on the sea floor (Ryan et al., 1978; Robb et al., 1981; Tucholke and Mountain, 1986) was older material recovered from the cores (Fig. 1). Although the age of the material removed is mostly quite young, the actual timing of when the failures occurred is difficult to determine (Lee, 2009-this issue).

\section{Discussion}

The improved understanding of submarine landslides along the U.S. Atlantic margin provided by the extensive multibeam bathymetric and backscatter data that are now available provides valuable insights into the differences between open-slope sourced and canyon sourced landslides, conditions that control their distribution, and conditions that may have contributed to triggering these landslides.

\subsection{Comparison of open-slope and canyon sourced landslides}

Canyon and open-slope sourced landslides are similar in some respects, but strikingly different in others. Both types are comprised of multiple failures (Figs. 2, 8, 9), but the distribution of headwall scarps and the volume removed by each failure suggests differences in how they are preconditioned for failure and evolve from initiation to deposition. The open-slope sourced failures mostly originate on the upper rise or lower slope where gradients are gentle. Sections of headwall scarps on the upper rise are partially obscured by landslide debris suggesting that subsequent failures were progressively farther upslope (Fig. 9). The volume of material removed with the formation of each headwall scarp is larger for the open-slope sourced landslides than for the canyon sourced ones (Chaytor et al., 2009-this issue). The volumes of the open-slope sourced landslide deposits can be much larger than their canyon-sourced counterparts as well (Fig. 3). By contrast, the canyon-sourced landslides originate in shallower water depths (Fig. 5a) in areas with steeper regional slopes (Fig. 7). They are also characterized by numerous gullies and small scarps in their source areas (Fig. 8), and can be considerably smaller in aerial extent 
and volume (Table 1 ) although the majority of both types cover areas of $100-5000 \mathrm{~km}^{2}$ (Fig. 10). The lengths of the two types of landslides, with the exception of the three largest open-slope sourced ones, are quite similar, but the difference in elevation of their source areas is striking (Fig. 5a) while their termination depths are quite similar (Fig. 5b). This difference may be due to the morphology of the rise that the landslides pass over. Most of the canyon sourced landslides are located off the Middle Atlantic and their runout paths extend onto the Chesapeake Drift, where the upper rise gradients are much gentler than northeast or southwest of this region (Fig. 4). Gradient of the source area, as has been pointed out by other authors (Booth et al., 1993; Huhnerbach et al., 2004), does not correlate with runout distance. Perhaps, the volume of the individual removal events (Chaytor et al., 2009-this issue), the physical properties of the source material (Locat et al., 2009-this issue), and the gradient of the rise over which they travel play larger roles in the runout distance of individual flows.

Tabulations of the length, width, and height (difference between source and termination depth) of the landslides mapped along the U.S. Atlantic margin allow comparisons to landslides from other regions. Hampton et al. (1996) compiled the lengths and heights of landslides available from the literature. Their results show the same general trend, but have more scatter than we found on this margin (Fig. 11). The increased scatter may be due to the more varied geological settings of the landslides from which they gathered their measurements (i.e. volcanic islands, carbonate escarpments, deltas, and active and passive margins). Huhnerbach et al. (2004) reported that landslides in the western North Atlantic are smaller and originate in shallower water depths than those found in the eastern North Atlantic. Their conclusion was based however on comparison of landslides in the eastern North Atlantic mapped with sidescan sonar and multibeam bathymetry (Weaver et al., 2000; Canals et al., 2004) while those in the western North Atlantic were mapped using widely spaced seismic profiles (Booth et al., 1993), or multibeam data limited to localized sections of the continental slope alone (McAdoo et al., 2000). The regional multibeam coverage that is now available suggests that landslides on the two sides of the North Atlantic are quite similar, and demonstrate the need for regional multibeam data sets if comparisons such as these are to be made.

\subsection{Geological controls on landslides}

Mapped landslides are not evenly distributed along this margin. Instead, they have the largest aerial coverage off the glacially influenced New England margin, and have the least aerial coverage on the part of the margin south of Cape Hatteras (Fig. 1). Furthermore, the distribution of the two landslide categories varies along the margin (Fig. 4). The open-slope sourced landslides mostly occur

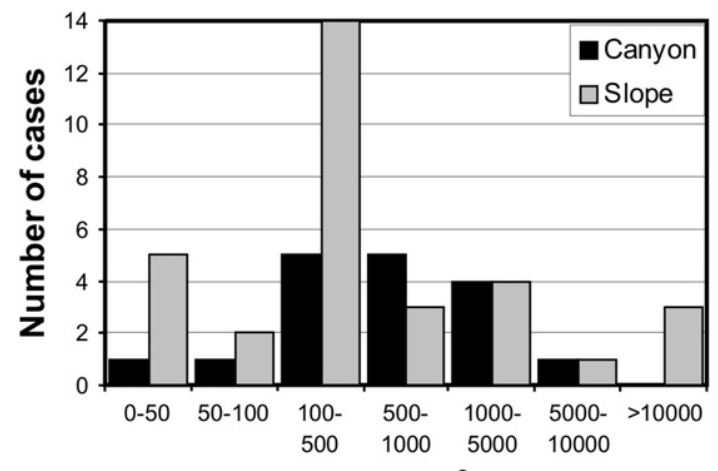

Area $\left(\mathrm{km}^{2}\right)$

Fig. 10. Graph comparing the area of canyon sourced and open-slope sourced landslides. Bin divisions are similar to those used by Booth et al. (1988).

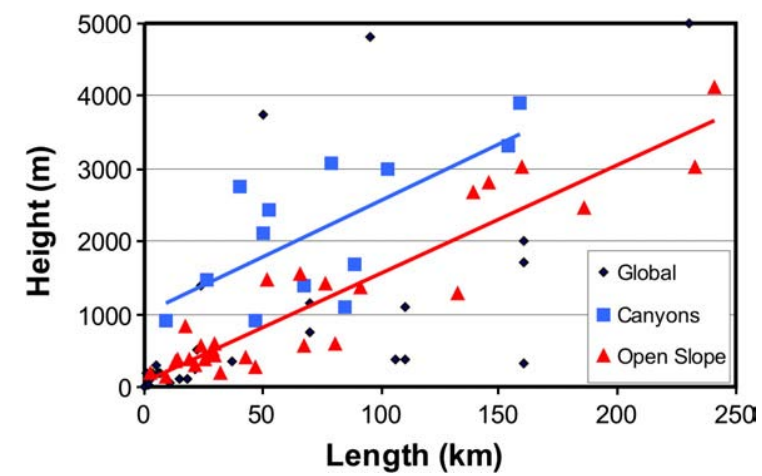

Fig. 11. Graph of the height (difference in depth between the headwall scarp and toe of the landslide) vs. length of the canyon-sourced landslides (blue squares) and openslope-sourced landslides (red triangles). The black diamonds are from Hampton et al. (1996). Linear regression lines are shown for the open slope (red line) and canyon (blue line) landslides.

downslope of thick Quaternary shelf-edge deposits with the exception of the two located south of Cape Hatteras that are associated with salt diapirs, and the canyon sourced ones are mostly located away from these large sediment sources (Fig. 4). While the source area is largely controlled by the development of the slope during the Quaternary, landslide runout length is controlled by processes that shaped the rise. East of Veatch Canyon and south of Norfolk Canyon, the steepest gradients are on the upper slope with a gradual but continuous decrease in gradient across the lower slope and rise. In these areas the runout length of both canyon-sourced and open-slope-sourced landslides can exceed $240 \mathrm{~km}$ (Fig. 4). By contrast, both types of landslides along the section of the margin between Veatch and Norfolk Canyons are all less than $130 \mathrm{~km}$ in length and do not extend across the $0.5^{\circ}$ gradient of the upper rise behind the Chesapeake Drift (Fig. 4). The combination of the abrupt change in slope at the slope-rise transition, and the gentler gradient of the upper rise appear to be responsible for the shorter runout lengths of landslides in this area.

Landslides were found to be more numerous and to cover a greater area of sea floor off areas that were affected by continental glaciers and large river systems during the last glaciation, and it appears that the shallow stratigraphy and higher sedimentation rates in these areas has a strong control on landslide distribution. In addition to the Quaternary deposits on the outer shelf and upper slope being thickest, seismic profiles show reflecting horizons with dips parallel to the sea floor (Uchupi and Emery, 1967; Rona, 1969; Uchupi, 1970; McGregor, 1981; O'Leary, 1986); a geometry that resulted from the progradation of the shelf-edge deltas. Rona (1969), McGregor (1981), and O'Leary (1986) have all suggested that the seaward dip of the underlying strata associated with these shelf-edge deltas may result in detachments along bedding planes. O'Leary $(1991,1993)$ suggested that some beds may be "weak layers" that would further pre-condition these deposits to failure.

The canyon-sourced landslides are most common between areas occupied by Quaternary shelf-edge deltas. In these areas, Quaternary sediment cover on the upper slope is thinner (Poag and Sevon, 1989) and is absent from large parts of the lower slope (Robb et al., 1981; Tucholke and Mountain, 1986).

The area south of Cape Hatteras, which was isolated from rivers during lowstands of sealevel by the Blake Plateau, has only $13 \%$ landslide cover. The two landslides in this southern region are in a different geologic setting to those farther north, and different processes contributed significantly to their formation. The headwall scarps of these failures are near salt domes, and so salt mobility (Dillon et al., 1982; Cashman and Popenoe, 1985; Popenoe et al., 1993) and continued activity of faults in the sediments overlying salt domes (Hornback et al., 2007) both have been suggested as triggering mechanisms. The decomposition of gas hydrates due to changes in sea 
level has also been suggested to have contributed to triggering these failures (Popenoe et al., 1993; Schmuck and Paull, 1993). The large earthquakes that have occurred on land shoreward of this area in New Madrid, Missouri in 1811-1812 and Charleston, South Carolina in 1866 (Bakun and Hopper (2004) along with the recent recording of small, shallow earthquakes along this section of the margin (Ekström, 2006) suggest that seismic activity may also have contributed to the formation of these landslides.

\subsection{Triggering mechanisms}

The triggering of landslides on the Atlantic margin is commonly attributed to earthquakes (Booth et al., 1993; Lee, 2009-this issue; ten Brink et al., 2009), but other processes including oversteepening (Lee, 2009-this issue), dissociation of gas hydrates during periods of lower sealevel (Booth et al., 1993; Dillon et al., 1993; Popenoe et al., 1993), and fluid discharge (Robb 1984; Dugan and Flemings, 2000; Person et al., 2003) may have pre-conditioned the material for failure. The mapping shown here suggests that some processes have had influence on canyon-sourced landslides and others on open-slope sourced landslides.

Oversteepening of the landslide source areas probably was not a major triggering mechanism for the landslides on this margin. The sea floor surrounding the source areas of the open-slope sourced landslides is on average less than $6^{\circ}$; well below the angle of repose. The sea floor surrounding the heads of the canyon-sourced landslides is steeper, and canyon walls can exceed $20^{\circ}$ (Fig. 4). Because of the steepness of the canyon walls, oversteepening may have contributed to small failures of sediment supplied to canyon heads during lowstands in sea level. The small size of the gullies and scarps in the canyon heads (Fig. 8) suggests individual failures were small however.

Dillon et al. (1993), Booth et al. (1993) and Popenoe et al. (1993) have suggested that the decomposition of gas hydrates during periods of lowered sea level might have contributed to triggering landslides. Maslin et al. (2004) and Hornbach et al. (2007) point out that gas hydrates are most susceptible to decomposition in response to lowered sea level if they occur in 200-600 m water depths. Sultan et al. (2004) suggest that hydrate dissociation in water depths as deep as $1200 \mathrm{~m}$ may have triggered the Storegga slide on the Norwegian margin. Of the two types of landslides we mapped, decomposition of gas hydrates may have caused some of the canyon head failures, but probably had less effect on the open-slope sourced landslides because the depths of their source areas are at much greater depths than those where hydrates are most susceptible to decomposition. Furthermore, geophysical mapping of bottom simulating reflectors (Tucholke et al., 1977; Dillon et al., 1986), an indicator of the presence of gas hydrates, has not identified them under the southern New England or Georges Bank parts of the margin where landslides have the greatest aerial extent.

Modeling of fluid discharge on the lower slope suggests this process may make the lower slope more prone to failure. Along the New Jersey margin, Robb (1984) suggested that groundwater discharged along the lower slope during periods of lower sea level. Dugan and Flemings (2000) suggested that rapid loading of permeable Miocene beds by Pleistocene sediment would increase the pore pressure in these beds with one consequence being increased slope failure where Miocene strata underlie the middle and lower slope. Hydrogeologic modeling of fresh water in Miocene strata under the southern New England shelf suggests that subglacial recharge from the Laurentide ice sheet would have extended offshore as far as the lower slope (Person et al., 2003). The source areas of the open-slope sourced landslides are concentrated on the lower slope off shelf-edge deltas where increased pore pressures due to rapid sediment loading or sub-glacial recharge would be concentrated. While beds with excess pore pressure may not have triggered the landslides, they may have reduced the stability of slope deposits sufficiently that small earthquakes associated with glacial rebound could trigger these large failures (ten Brink et al., 2009). If increased pore pressure or groundwater discharge did play a role, they probably were most significant in the deltaic settings where sedimentation might be sufficient to increase pore pressures in underlying confined beds. Because Quaternary sediments are thickest along the Georges Bank and southern New England sections of the margin, this seems like the place that would show the greatest effect of this process, and the large aerial extent of open-slope sourced landslides on this margin may in part be a consequence of the presence of over-pressured beds.

\section{Summary}

The open-slope sourced landslides are larger in overall volume than canyon-sourced ones and as such are the dominant means of rapid large-scale margin modification (Fig. 4). Because of the large volumes associated with these open-slope sourced landslides, they have the most potential to initiate tsunamis (Murty, 2003); however their significance may be diminished depending on the size of individual failure events (Chaytor et al., 2009-this issue) and mode of failure and the rate at which it occurs (Locat et al., 2009-this issue; Geist et al., 2009-this issue). The presence of several headwall scarps above many of these large landslides (Fig. 9) points to their being the result of multiple retrogressive failures rather than a single event. Even so, the volume of material that was removed to form an individual scarp can in some cases be large enough to generate a tsunami (Hornbach et al., 2007; Geist et al., 2009-this issue; Locat et al., 2009this issue). Whereas conditions related to glaciation, including oversteepening and weak layers associated with deltaic sedimentation (O'Leary, 1991,1993), excess pore pressures in response to sediment loading or glacial recharge (Dugan and Flemings, 2000; Person et al., 2003), and earthquakes associated with glacial rebound (ten Brink et al., 2009), appear to have contributed to the abundance of landslides off the glacially influenced part of the margin, these are not the only processes that have been instrumental. Off the Middle Atlantic States, the large open-slope-sourced landslides occur only off more localized river-fed shelf-edge deltas (Figs. 2, 4). Here, depositional processes and excess pore pressure conditions would be similar to those on glacially influenced margins, but earthquakes would not be as readily associated with glacial rebound. The large landslides off the Carolina Trough are well removed from glaciated areas, and here the upward migration of salt along normal faults may be the cause of increased activity of small earthquakes in this area (Ekström, 2006), and these earthquakes along with oversteepening of the sea floor due to salt movement could lead to repeated slope failures (Hornbach et al., 2007).

\section{Acknowledgments}

The U.S. Nuclear Regulatory Commission and the U.S. Geological Survey are acknowledged for their support of this research. Work was funded by US Nuclear Regulatory Commission grant N6480 Physical study of tsunami sources. We thank James Gardner from the University of New Hampshire for his willingness to make multibeam bathymetry that they collected available to us. Valerie Paskevich and VeeAnn Cross assisted in reformatting and reprojecting data sets used in this study. Helpful comments by Carolyn Ruppel, Homa Lee, Jacques Locat, David Piper, and an anonymous reviewer improved an earlier version of this manuscript.

\section{References}

Austin, J.A., Uchupi, E., Shaughnessy, D.R., Ballard, R.D., 1980. Geology of New England passive margin. Am. Assoc. Petrol. Geol. Bull. 64, 501-526.

Bakun, W.H., Hopper, M.G., 2004. Magnitudes and locations of the 1811-1812 New Madrid, Missouri, and the 1886 Charleston, South Carolina, earthquakes. Bull. Seismol. Soc. Am. 94, 64-75. 
Bondevik, S., Lovholt, F., Harbitz, C.B., Mangerud, J., Dawson, A., Svendsen, J.I., 2005. The Storegga Slide tsunami; comparing field observations with numerical simulations. Mar. and Petrol. Geol. 22, 195-208.

Booth, J.S., O'Leary, D.W., 1991. A statistical overview of mass movement characteristics on the North American Atlantic outer continental margin. Mar. Geotechnol. 10, $10-18$.

Booth, J.S., O'Leary, D.W., Popenoe, P., Robb, J.M., McGregor, B.A., 1988. Map and tabulation of Quaternary mass movements along the United States-Canadian Atlantic continental slope from $32^{\circ} 00^{\prime}$ to $47^{\circ} 00^{\prime} \mathrm{N}$ latitude. U.S.G.S. Misc. Field Studies Map MF-2027.

Booth, J.S., O'Leary, D.W., Popenoe, P., Danforth, W.W., 1993. U.S. Atlantic continental slope landslides: their distribution, general attributes, and implications. In: Schwab, W.C., Lee, H.J., Twichell, D.C. (Eds.), Submarine Landslides: Selected Studies in the U.S. Exclusive Economic Zone: U.S.G.S. Bulletin no. 2002, pp. 14-22.

Canals, M., Lastras, G., Urgeles, R., Casamor, J.L., Mienert, J., Cattaneo, A., De Batist, M., Haflidason, H., Imbo, Y., Laberg, J.S., Locat, J., Long, D., Longva, O., Masson, D.G. Sultan, N., Trincardi, F., Byrn, P., 2004. Slope failure dynamics and impacts from seafloor and shallow sub-seafloor geophysical data: case studies from the COSTA project. Mar. Geol. 213, 9-72.

Cashman, K.V., Popenoe, P., 1985. Slumping and shallow faulting related to the presence of salt on the continental slope and rise off North Carolina. Mar. Petrol. Geol. 2, 260-271.

Chaytor, J.D., Twichell, D.C., ten Brink, U.S., Buczkowski, B.J., Andrews, B.D., 2007. Revisiting submarine mass movements along the U.S. Atlantic continental margin: Implications for tsunami hazards. In: Lykousis, V., Sakellariou, D., Locat, J. (Eds.), Submarine Mass Movements and Their Consequences. Springer, Netherlands, pp. 395-403.

Chaytor, J.D., ten Brink, A.R., Solow, J.D., Andrews, B.D., 2009. Size distribution of submarine landslides along the U.S. Atlantic margin. Mar. Geol. 264,16-27 (this issue).

Dillon, W.P., Popenoe, P., Grow, J.A., Klitgord, K.D., Swift, B.A., Paull, C.K., Cashman, K.V., 1982. Growth faulting and salt diapirism: their relationship and control in the Carolina Trough, eastern North America. In: Watkins, J.S., Drake, C.L. (Eds.), Studies in Continental Margin Geology. Am. Assoc. Petrol. Geol. Memoir, vol. 34, pp. 21-46.

Dillon, W.P., Manheim, F.T., Jansa, L.F., Palmason, G., Tucholke, B.E., Landrun, R.S., 1986. Resource potential of the western North Atlantic. In: Vogt, P.R., Tucholke, B.E. (Eds.), The Geology of North America, Volume M, The Western North Atlantic Region. Geol. Soc. Am. , pp. 661-676.

Dillon, W.P., Lee, M.W., Fehlhaber, K., Coleman, D.F., 1993. Gas hydrates on the Atlantic continental margin of the United States - controls and concentration. In: Howell, D.G. (Ed.), The future of energy gases. U.S. Geol. Survey Prof. Paper 1570, pp. 313-330.

Dugan, B., Flemings, P.B., 2000. Overpressure and fluid flow in the New Jersey continental slope: implications for slope failure and cold seeps. Sci. 289, 288-291.

EEZ-SCAN 87, 1991. Atlas of the U.S. Exclusive Economic Zone, Atlantic continental margin. U.S.G.S. Misc. Investigations Series I-2054. 174 pp.

Ekström, G., 2006. Global detection and location of seismic sources by using surface waves. Bull. Seismol. Soc. Am 96, 1201-1212.

Embley, R.W., 1980. The role of mass transport in the distribution and character of deep ocean sediments with special reference to the North Atlantic. Mar. Geol. 38, 23-50.

Embley, R.W., Jacobi, R.D. 1986. Mass wasting in the western North Atlantic. In: Vogt, P.R., Tucholke, B.E. (Eds.), The Western North Atlantic Region: Geology of North America, v. M, Geol. Soc. Am., Boulder, CO, pp. 479-490.

Fine, I.V., Rabinovich, A.B., Bornhold, B.D., Thomson, R., Kulikov, E.A., 2005. The Grand Banks landslide-generated tsunami of November 18,1929: preliminary analysis and numerical modeling. Mar. Geol., 215, 45-57.

Gardner, J.V., Mayer, L.A., Armstrong, A.A., 2006. Mapping supports potential submission to U.N. Law of the Sea. EOS Trans., Am. Geophys. Union 87, 157-159.

Geist, E.L., Lynett, P.J., Chaytor, J.D., 2009. Hydrodynamic modeling of tsunamis from the Currituck Landslide. Mar. Geol. 264, 41-52 (this issue).

Gisler, G., Weaver, R., Gittings, M.L., 2006. SAGE calculations of the tsunami threat from La Palma. Sci. Tsunami Hazards 24, 288-301.

Hampton, M.A., Lee, H.J., Locat, J., 1996. Submarine landslides. Rev. Geophys. 34, 33-59.

Heezen, B.C., Ewing, M., 1952. Turbidity currents and submarine slumps, and the Grand Banks earthquake. Am. J. Sci. 250, 849-873.

Heezen, B.C., Tharp, M., Ewing, M., 1959. The Floors of the Oceans, 1, The North Atlantic. Geol. Soc. Am. Special Paper, vol. 65.122 pp.

Hornbach, M., Lavier, L., Ruppel, C., 2007. Triggering mechanism and tsunamogenic potential of the Cape Fear Slide complex, U.S. Atlantic margin. Geochem., Geophys. Geosyst. 8, 16. doi:10.1029/2007GC001722.

Huhnerbach, V., Masson, D.G., partners of the COSTA-Project, 2004. Landslides in the North Atlantic and its adjacent seas: an analysis of their morphology, setting and behavior. Mar. Geol. 213, 343-362.

Jenner, K.A., Piper, D.J.W., Campbell, D.C., Mosher, D.C., 2007. Lithofacies and origin of late Quaternary mass transport deposits in submarine canyons, central Scotian Slope, Canada. Sedimentol. 54, 19-38.

Lee, H.J., 2009. Timing of occurrence of large submarine landslides on the Atlantic Ocean margin. Mar. Geol. 264, 53-64 (this issue).

Locat, J., Lee, H.J., 2002. Submarine landslides: advances and challenges. Can. Geotech. J. $39,193-212$.

Locat, J., Lee, H., ten Brink, U., Twichell, D., Geist, E., Sansoucy, M., 2009. Geomorphology, stability and mobility of the Currituck Slide. Mar. Geol. 264, 28-40 (this issue).

Mader, C.L., 2001. Modeling the La Palma landslide tsunami. Sci. Tsunami Hazards 19, $150-170$.

Maslin, M., Owen, M., Day, S., Long, D., 2004. Linking continental-slope failures and climate change: testing the clathrate gun hypothesis. Geology 32, 53-56.
Masson, D.G., Harbitz, C.B., Wynn, R.B., Pedersen, G., Lovholt, F., 2006. Submarine landslides: processes, triggers, and hazard prediction. Phil. Trans. Royal Soc. A. 364, 2009-2039.

McAdoo, B.G., Pratson, L.F., Orange, D.L., 2000. Submarine landslide geomorphology, U.S. continental slope. Mar. Geol. 169, 103-136.

McGregor, B.A., 1981. Smooth seaward-dipping horizons - an important factor in seafloor stability? Mar. Geol. 39, M89-M98.

McMaster, R.L., Ashraf, A., 1973. Drowned and buried valleys on the southern New England continental shelf. Mar. Geol. 15, 249-268.

Mountain, G.S., Tucholke, B.E., 1985. Mesozoic and Cenozoic geology of the U.S. Atlantic continental slope and rise. In: Poag, C.W. (Ed.), Geologic Evolution of the United States Atlantic Margin. Nostrand Reinhold, New York, pp. 293-341.

Murty, T.S., 2003. Tsunami wave height dependence on landslide volume. Pure Appl Geophys. 160, 2147-2153.

Oldale, R.N., 1992. Cape Cod and the Islands: the Geologic Story. Parnassus Imprints, East Orleans, MA. 208 pp.

O'Leary, D.W., 1986. The Munson-Nygren slide: a major lower-slope slide off Georges Bank. Mar. Geol. 72, 101-114.

O'Leary, D.W., 1991. Structure and morphology of submarine slab slides: clues to origin and behavior: Mar. Geotechnol. 10, 53-69.

O'Leary, D.W., 1993. Submarine mass movement, a formative process of passive continental margins: the Munson-Nygren landslide complex and the southeast New England landslide complex. In: Schwab, W.C., Lee, H.J., Twichell, D.C. (Eds.), Submarine Landslides: Selected Studies in the U.S. Exclusive Economic Zone. U.S.G.S. Bulletin no. 2002, pp. 23-39.

Person, M., Dugan, B., Swenson, J.B., Urbano, L., Stott, C., Taylor, J., Willett, M., 2003. Pleistocene hydrogeology of the Atlantic continental shelf, New England. Geol. Soc Am. Bull. 115, 1324-1343.

Piper, D.J.W., McCall, C., 2003. A synthesis of the distribution of submarine mass movements on the eastern Canadian margin. In: Locat, J., Mienert, J. (Eds.), Submarine Mass Movements and their Consequences. Kluwer, Dordrecht, Netherlands, pp. 291-298.

Poag, C.W., 1978. Stratigraphy of the Atlantic continental shelf and slope of the United States. Annu. Rev. Earth Planet. Sci. 6, 251-280.

Poag, C.W., 1985. Geologic Evolution of the United States Atlantic margin. Van Norstrand Reinhold, New York, NY. 384 p.

Poag, C.W., 1991. Rise and demise of the Bahama-Grand Banks gigaplatform, northern margin of the Jurassic proto-Atlantic seaway. Mar. Geol. 102, 63-130.

Poag, C.W., 1992. U.S. Middle Atlantic continental rise: provenance, dispersal, and deposition of Jurassic to Quaternary sediments. In: Poag, C.W., de Graciansky, P.C. (Eds.), Geologic Evolution of Atlantic Continental Rises. Van Nostrand Reinhold, New York, pp. 100-156.

Poag, C.W., Sevon, W.D., 1989. A record of Appalachian denudation in postrift Mesozoic and Cenozoic sedimentary deposits of the U.S. middle Atlantic continental margin. Geomorphol. 2, 119-157.

Popenoe, P., Dillon, W.P., 1996. Characteristics of the continental slope and rise off North Carolina from GLORIA and seismic-reflection data: the interaction of downslope and contour current processes. In: Gardner, J.V., Field, M.E., Twichell, D.C. (Eds.) Geology of the United States Seafloor: the view from GLORIA. Cambridge Univ. Press, Cambridge, UK, pp. 59-79.

Popenoe, P., Schmuck, E.A., Dillon, W.P., 1993. The Cape Fear Landslide: slope failure associated with salt diapirism and gas hydrate decomposition. In: Schwab, W.C., Lee, H.J., Twichell, D.C. (Eds.), Submarine Landslides: Selected Studies in the U.S. Exclusive Economic Zone. U.S.G.S. Bulletin no. 2002, pp. 40-53.

Pratson, L.F., Laine, E.P., 1989. The relative importance of gravity-induced versus current-controlled sedimentation during the Quaternary along the mideast U.S. Outer continental margin revealed by $3.5 \mathrm{kHz}$ echo character. Mar. Geol. 89, 87-126.

Prior, D.B., Coleman, J.M., Doyle, E.H., 1984. Antiquity of the continental slope along the Middle-Atlantic margin of the United States. Sci. 223, 926-928.

Prior, D.B., Doyle, E.H., Neurauter, T., 1986. The Currituck Slide, Mid-Atlantic continental slope; revisited. Mar. Geol. 73, 25-45.

Robb, J.M., 1984. Spring sapping on the lower continental slope, offshore New Jersey. Geol. 12, 278-282.

Robb, J.M., Hampson, J.C., Twichell, D.C., 1981. Geomorphology and sediment stability of a segment of the U.S. Continental Slope off New Jersey. Sci. 211, 935-937.

Rona, P.A., 1969. Middle Atlantic Continental Slope of United States: deposition and erosion. Am. Assoc. Petrol. Bull. 53, 1453-1465.

Ryan, W.B.F., Cita, M.B., Miller, E.L., Hanselman, D., Nesterhoff, W.D., Hecker, B. Nibbelink, M., 1978. Bedrock geology in New England submarine canyons. Oceanol Acta. 1, 233-254.

Schlee, J.S., Fritsch, J., 1983. Seismic stratigraphy of the Georges Bank basin complex, offshore New England. In: Watkins, J.S., Drake, C.L. (Eds.), Studies in Continental Margin Geology. AAPG Memoir, vol. 34, pp. 223-251.

Schlee, J.S., Robb, J.M., 1991. Submarine processes of the middle Atlantic continental rise based on GLORIA imagery. Geol. Soc. Am. Bull. 103, 1090-1103.

Schmuck, E.A., Paull, C.K., 1993. Evidence for gas accumulation associated with diapirism and gas hydrates at the head of the Cape Fear Slide. Geo. Mar. Lett. 13, 145-152.

Sultan, N., Cochonat, P., Foucher, J.-P., Mienert, J., 2004. Effect of gas hydrates melting on seafloor slope instability. Mar. Geol. 213, 379-401.

ten Brink, U.S., Lee, H.J., Geist, E.L., Twichell, D.C., 2009. Assessment of tsunami hazard to the U.S. East Coast using relationships between submarine landslides and earthquakes. Mar. Geol. 264, 65-73 (this issue).

Tripsanas, E.K., Piper, D.J.W., Jenner, K.A., Bryant, W.R., 2008. Submarine mass-transport facies: new perspectives on flow processes from cores on the eastern North Atlantic margin. Sedimentol. 55, 97-136. 
Tucholke, B.E., Bryan, G.M., Ewing, J.I., 1977. Gas-hydrate horizons detected in seismicprofiler data from the western North Atlantic. Am. Assoc. Petrol. Geol. Bull., 61, 698-707.

Tucholke, B.E., Mountain, G.S., 1986. Tertiary paleoceanography of the western North Atlantic Ocean. In: Vogt, P.R., Tucholke, B.E. (Eds.), The Geology of North America, Volume M, The Western North Atlantic Region. Geol. Soc. Am., pp. 631-650.

Uchupi, E., 1970. Atlantic continental shelf and slope of the United States - shallow structure. U.S.G.S. Prof. Paper 529-I, p. 44.

Uchupi, E., Emery, K.O., 1967. Structure of continental margin off Atlantic coast of United States. Am. Assoc. Petrol. Geol. Bull. 51, 223-234.
Vogt, P.R., Tucholke, B.E. (Eds.), 1986. The Geology of North America, Volume M, The Western North Atlantic Region: Geol. Soc. Am., Boulder, CO, p. 696.

Weaver, P.P.E., Wynn, R.B., Kenyon, N.H., Evans, J., 2000. Continental margin sedimentation, with special reference to the northeast Atlantic margin. Sedimentol. 47, 239-256.

Weed, E.G.A., Minard, J.P., Perry, W.J., Rhodehamel, E.C., Robbins, E.I., 1974. Generalized pre-Pleistocene geologic map of the northern United States Atlantic continental margin: U.S.G.S. Misc. Investigations Series I-861, scale 1:1,000,000. 